\title{
A STUDY ON OXIDATIVE STRESS AND PERIPHERAL BLOOD PARAMETERS OF COWS BRED IN THE AREA EXPOSED TO DEPLETED URANIUM AMMUNITION
}

STEVANOVIĆ JELKA*, KOVAČEVIĆ-FILIPOVIĆ MILICA*, VLAŠKI MARIJA**, POPOVIĆ DRAGANA*, BOROZAN SUNČICA*, JOVIĆ S* and BOŽIĆ TATJANA*

${ }^{*}$ Faculty of Veterinary Medicine, Belgrade, ** Institute for Medical Research, Belgrade

(Received 24. February 2005)

The paper presents results of the study on depleted uranium (DU) health effects on cows bred in areas exposed to DU ammunition, during NATO bombing of Serbia and Montenegro in 1999. The samples of animal blood, soils and feed were collected randomly in the region of Bujanovac, in 2003. Complete blood cells count was performed according to standard laboratory procedures. Concentration of red blood cells malondialdehyde (RBC MDA) and erythrocyte superoxid dismutase (SOD) activity were determined spectrophotometrically. The functional activity of leukocytes was investigated by NBT reduction and adhesion test. Activity of the radionuclides was determined by standard gamma spectrometry.

The obtained results of complete red blood cells count indicate normocytic normochromic anaemia. Considerably increased RBC MDA concentration suggests a violent oxidative stress in cows bred in the exposed area, although the activity of their RBC antioxidant enzyme $S O D$ was in the range of values obtained in the control group. The total number of leukocytes and the differential leukocyte counts were within the physiological range. NBT reduction test revealed the absence of leukocyte oxidative burst, which pointed to the absence of inflammation. A significant decrease of granulocyte adhesiveness, pointed at partial impairment of granulocyte functional activity. The activity of ${ }^{238} \mathrm{U} / 235 \mathrm{U}$ in soils and feed was below the minimal detectable concentration $\left(10^{-3} \mathrm{~Bq} / \mathrm{kg}\right)$, while the content of natural ${ }^{226} \mathrm{Ra}$ and $\left.{ }^{232} \mathrm{Th}\right)$ and anthropogenic $\left({ }^{137} \mathrm{Cs}\right)$ radionuclides in soils were within the average values for the region, except for low levels of ${ }^{40} \mathrm{~K}$ - indicating soils impoverishment in potassium.

Key words: cows, depleted uranium (DU), oxidative stress, environment, peripheral blood, RBC SOD, RBC MDA.

\section{INTRODUCTION}

Uranium is a naturally occurring primordial radioactive element. It is a mixture of three radioisotopes, with different relative abundance: ${ }^{238} U(99 \%),{ }^{235} U$ 
$(0.71 \%)$ and ${ }^{234} \cup(0.006 \%)$, and a half-life of $10^{9}$ years. Depleted uranium - DU (the content of ${ }^{235} \mathrm{U}$ of about $0.2-0.3 \%$ ) is a waste material of low radioactivity, a byproduct of uranium processing in nuclear reactors or production of nuclear weapons. Due to its high density $\left(19,8 \mathrm{~g} / \mathrm{cm}^{3}\right)$, penetrability and pyrophoricity, depleted uranium was used for the first time as a military weapon in the Gulf War, in Iraq in 1991.

According to official records, there were 500.000 DU missiles (equivalent to $3600 \mathrm{~kg}$ of U-oxide) used during NATO bombing of Yugoslavia in 1999., yielding an activity of $18.3 \times 10^{10} \mathrm{~Bq}$. Eleven locations in South Serbia (Bujanovac, Vranje etc.) and Montenegro were hit. The highest contamination measured in soils on the targeted sites was $200,000-250,000 \mathrm{BqU} / \mathrm{kg}$ soil. Targeted sites were isolated and decontaminated and missile fragments stored as radioactive waste (FM Report, 2000; Popović et al., 2002).

Natural and depleted uranium are chemically identical, expressing equal biokinetic behaviour and effects on the environment, on both humans and animals (Ribera, 1996). Uranium, both chemically toxic and radioactive, is water soluble and thus easily taken up by plants hence entering food chains and soil/waters systems. Once in the environment, DU particles can be inhaled or can penetrate deep into the soil, contaminating soils, waters and vegetation (Lee et al., 2001). Although present in the environment, uranium seems to have no important metabolic functions and is regarded as non-essential (Berlin and Rudell, 1986). Its toxic effects are well recognized from animal health studies (Domingo, 2001).

Long-term effects of DU on the environment include the initial exposure of the local population and animals, due to DU particles resuspended from contaminated soils and food/feed as well as eventual exposure from contaminated waters, or by inhaling dust containing particles with uranium (Ribera, 1996). Generally, the chemical toxic effects of DU occur at lower exposure levels than the radiotoxic one, except for exposure by inhalation.

Following ingestion or inhalation, DU appears in the bloodstream (Ribera, 1996). Although rapidly excreted in urine (nearly $90 \%$ in the first 3 months), DU subsequently accumulates in kidneys, skeleton, lungs, liver and heart (Ribera, 1996; Duraković, 1999; Pellmar, 1999; Roth et al., 2003). Deposited DU exhibits a highly toxic effect, as a result of alpha emission, followed by ionisation (Cothern and Lappenbuch, 1983) and leading to production of free radicals (Bogdan et al., 2000). Paradoxally, the smaller the concentration of free radicals present in body fluids, the greater their efficiency in producing damages (Graeub, 1994). The damage is not the direct result of radiation, rather it occurs indirectly as a result of reactive oxygen species created by the radiation (Graeub, 1994). When generation of free oxygen species exceeds the level that the protective system can control, cell proteins and lipids are damaged (Lorimore and Wright, 2003), thus weakning or even destroying the membrane thus expressing different clinical symptoms (Petkau, 1971; Petkau, 1972; Nussbaum and Kohnlein, 1994).

The aim of this study was to determine the concentration of the basic marker of oxidative stress, red blood cells malondialdehyde (RBC MDA) and the activity of red blood cells superoxid dismutase (RBC SOD), as well as other relevant blood parameters (complete blood count, hemoglobin concentration, functional activity 
Stevanović Jelka et al. A study on oxidative stress and peripheral blood parameters

of cows bred in the area exposed to depleted uranium ammunition

of leucocytes etc.) and to see whether they could be correlated with the data on the content of DU that entered the environment during the bombing in 1999.

\section{MATERIAL AND METHODS}

\section{Experimental animals, blood and food sampling}

The samples of cows' blood, soils and feed were collected randomly on 6 locations in the region of Bujanovac (Novo Selo and Borovac) in the spring of 2003. Blood samples were taken by punction of $v$. jugularis (using acid-citrate dextrose as anticoagulant) from 20 clinically healthy cows (Simental type, age 613 years). Animals, randomly selected from 9 households, were held on pastures with free access to water, near the area of the air strikes. In the control group there were 10 cows from a location not exposed to DU. There were no significant differences among the groups (considering age, health status, nutrition etc.) that could affect the examined parameters in the blood.

\section{Haematological and biochemical parameters}

Complete blood cell count was performed according to standard laboratory procedures. Using colorimetric procedure (spectrophotometer Specord M40, Karl Zeiss, Jena), RBC MDA concentrations were determined at $535 \mathrm{~nm}$ (Uchiyama et al., 1978), RBC SOD activity at $480 \mathrm{~nm}$ (Misra and Fridovich, 1972) and hemoglobin concentration was detected at $540 \mathrm{~nm}$ (Tentori et al., 1981).

\section{Functional activity of peripheral blood leukocytes}

The activation of isolated peripheral blood leukocytes was evaluated by cytochemical assay for the respiratory burst (Monboisse et al., 1991) measured by intracellular reduction of nitroblue tetrazolim salt (NBT, MERCK, Germany). To determine the spontaneous or induced reduction of NBT, leukocytes were incubated only in Dulbeco's modified Eagle's medium (DMEM, Sigma Chemicals Co., USA) or in $50 \mathrm{ng} / \mathrm{ml}$ PMA (phorbol-miristat-acetat; Sigma Chemicals Co., USA), respectively. Formazan produced by cells was measured spectrophotometrically at $540 \mathrm{~nm}$ by ELISA 96-well plate reader (Labsystems Multiskan PLUS, Finland). Adhesion of leukocytes to plastics was performed by a modified assay initially described by Oez et al., (1990). To measure spontaneous

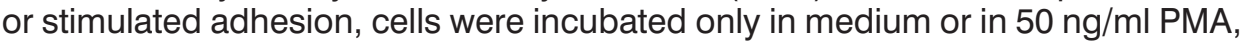
and the absorbance at $540 \mathrm{~nm}$ was measured by ELISA 96-well plate reader.

\section{Activity of radionuclides in soils and feed}

Activity of the radionuclides in soils and feed (corn and wheat) was determined on HPGe detector (ORTEC, relative efficiency $23 \%$ ) by standard gamma spectrometry. Geometric calibration was performed with a reference epoxie source (National Measuring Institute, Prague; $250 \mathrm{~g}$; activity of $55,10 \mathrm{kBq}$ measured on 10.3.2001). Counting times were from 61.000-67.500 s. Total standard error of the method was $20 \%$. 


\section{Statistical data}

Statistical analysis was performed by Microsoft Excel 2000 program. Descriptive statistic tools and unpaired Student's $\mathrm{t}$ - test were applied. $P$ value less then 0.05 was considered significant. All estimated values are given as means (MV) \pm standard error (SE).

\section{RESULTS}

\section{Biochemical and Hematological Measurements}

All examined animals had significantly lower red blood cell number $(p<0.001)$, hemoglobin concentration $(p<0.05)$ and PCV values $(p<0.05)$ compared to the control group. Calculated hematological indices of mean corpuscular volume (MCV) and mean corpuscular hemoglobin concentration (MCHC) indicate normocytic normohromic anemia and correspond with data obtained by microscopic examination of blood smears. The exposed group of cows had significantly increased RBC MDA $(p<0.001)$, but unchanged SOD activity compared to the control group (Table 1).

Table 1. The number of erythrocytes $(\mathrm{Er})$, hemoglobin concentration $(\mathrm{Hb})$, packed cell volume (PCV), red blood cells superoxid dismutase (SOD) activity and concentration of red blood cells malondialdehyde (RBC MDA) in cows' blood

\begin{tabular}{|l|c|c|c|c|}
\hline \multirow{2}{*}{} & \multicolumn{2}{|c|}{$\begin{array}{c}\text { EXPOSED GROUP } \\
(\mathrm{n}=20)\end{array}$} & \multicolumn{2}{c|}{$\begin{array}{c}\text { CONTROL GROUP } \\
(\mathrm{n}=10)\end{array}$} \\
\cline { 2 - 5 } & $\mathrm{MV}$ & $\mathrm{SE}$ & $\mathrm{MV}$ & $\mathrm{SE}$ \\
\hline \hline $\mathrm{Er}(\mathrm{\times 10} / \mathrm{L} / \mathrm{L})$ & $5.41^{* * *}$ & 0.17 & 7.00 & 0.132 \\
\hline $\mathrm{Hb}(\mathrm{g} / \mathrm{L})$ & $95.37^{*}$ & 5.84 & 110.00 & 4.94 \\
\hline $\mathrm{PCV}(\%)$ & $28.85^{*}$ & 1.57 & 35.00 & 2.19 \\
\hline $\mathrm{MCV}(\mathrm{fL})$ & 54 & 3.7 & 50 & 3.5 \\
\hline $\mathrm{MCH}(\mathrm{pg})$ & 17 & 0.7 & 16 & 0.8 \\
\hline $\mathrm{MCHC}(\mathrm{g} / \mathrm{L})$ & 345 & 25.3 & 325 & 27.3 \\
\hline $\mathrm{SOD}(\mathrm{U} / \mathrm{gHb})$ & 3774 & 151 & 3783 & 151 \\
\hline $\mathrm{RBC} \mathrm{MDA}(\mathrm{nM} / \mathrm{gHb})$ & $1.95^{* * *}$ & 0.22 & 0.017 & 0.002 \\
\hline
\end{tabular}

Significance at ${ }^{*} \mathrm{p}<0.05 ;{ }^{* *} \mathrm{p}<0.001$ vs. control group

Number of leukocytes $\left(6.6 \pm 0.46 \times 10^{9} / \mathrm{L}\right)$, relative contribution of lymphocytes $(59.22 \pm 1.92 \%)$, monocytes $(4.62 \pm 0.81 \%)$ and all granulocytes $(35.88 \pm 1.8 \%)$ of examined cows were within the physiological range.

The rate of NBT reduction in vitro (Table 2 ) indicates the absence of changes in spontaneous and PMA-stimulated NBT reduction in the leukocytes of the exposed group vs. controls. On the contrary, spontaneous and stimulated 
Acta Veterinaria (Beograd), Vol. 55. No. 4, 269-278, 2005.

Stevanović Jelka et al. A study on oxidative stress and peripheral blood parameters of cows bred in the area exposed to depleted uranium ammunition

adhesion of leukocytes were significantly lower $(p<0.01)$ in the group of cows from areas hit by DU ammunition, compared to the control (Table 2).

Table 2. The results on spontaneous and PMA-stimulated NBT reduction test and adhesion test of cows' peripheral blood leukocytes

\begin{tabular}{|c|c|c|c|c|c|c|c|c|}
\hline & \multicolumn{3}{|c|}{ NBT REDUCTION TEST } & \multicolumn{4}{c|}{ ADHESION } \\
\cline { 2 - 9 } & \multicolumn{2}{|c|}{ PMA 0 ng/ml } & \multicolumn{2}{c|}{ PMA 50 ng/ml } & \multicolumn{2}{c|}{ PMA 0 ng/ml } & \multicolumn{2}{c|}{ PMA 50 ng/ml } \\
\cline { 2 - 9 } & Control & $\begin{array}{c}\text { Exp. } \\
\text { group }\end{array}$ & Control & $\begin{array}{c}\text { Exp. } \\
\text { group }\end{array}$ & Control & $\begin{array}{c}\text { Exp. } \\
\text { group }\end{array}$ & Control & $\begin{array}{c}\text { Exp. } \\
\text { group }\end{array}$ \\
\hline \hline MV & 0.504 & 0.521 & 0.992 & 0.865 & 0.313 & $0.07^{* * *}$ & 0.371 & $0.218^{* *}$ \\
\hline SE & 0.07 & 0.05 & 0.2 & 0.08 & 0.02 & 0.01 & 0.04 & 0.06 \\
\hline
\end{tabular}

Significance at ${ }^{* *} p<0.01$ and ${ }^{* * *} p<0.001$ vs. control

\section{Radioactivity Measurements}

The results of determination of natural and anthropogenic radionuclides content in soils sampled at the sites on wich the animals were bred on, are presented in Table 3. The results represent the mean values from the 6 sampling sites, as there were no significant differences found in the contents of radionuclides in soils from different sites (Božic et al., 2003).

Table 3. Content of radionuclides $(\mathrm{Bq} / \mathrm{kg})$ in examined soils

\begin{tabular}{|c|c|c|c|c|}
\hline Radionuclide & ${ }^{226} \mathrm{Ra}$ & ${ }^{232} \mathrm{Th}$ & ${ }^{40} \mathrm{~K}$ & ${ }^{137} \mathrm{Cs}$ \\
\hline \hline MVSE & $23 \pm 3.4$ & $11 \pm 1.7$ & $167 \pm 27$ & $46 \pm 7.3$ \\
\hline
\end{tabular}

The activity of ${ }^{238} \mathrm{U} /{ }^{235} \mathrm{U}$ in the examined samples of soils were below the minimal detectable concentration (MDC) for the method $\left(10^{-3} \mathrm{Bg} / \mathrm{kg}\right)$, while the content of other natural and anthropogenic radionucldes was within the average range of values for the region, except for ${ }^{40} \mathrm{~K}$, indicating that the analzyed soils are poor in potassium. As for the feed, due to small quantities of the samples, all radionuclides activities were below the minimal detectable concentrations for the method $\left(10^{-3} \mathrm{~Bq} / \mathrm{kg}\right.$ dry weight), except for natural ${ }^{40} \mathrm{~K}$, the content of which was within the average values for the region (Todorovic et al., 2001).

\section{DISCUSSION}

After being in the scientific focus of interest in the sixties, seventies and again in the eighties after the nuclear plant accident at Chernobyl in 1986, the risks and effects of low doses of radiation came into public and scientific interest once again, while studying the environmental and health effects of DU ammunition 
used in the Gulf War in 1991., NATO intervention in Bosnia and Herzegovina in 1994., and during NATO bombing of Serbia and Montenegro in 1999.

Long-term exposure to low doses of DU induce an increased production of highly reactive oxygen species, such as superoxide and hidroxyl anions (Bogdan et al., 2000), which when attracted to the cell membane, set off a chain reaction successively oxydizing the membrane molecules and provoking different tissue damages and eventually the overall failure of the immune system (Waterfall et al., 1997; Graeub, 1994). Due to different individual repair mechanisms, the manifestations to low level exposure doses are individually very specific. According to some studies, chronical exposures to low-doses of radiation could be even more damaging than the doses of the same level received accidentally by short length medical X-rays (Petkau, 1972, Graeub, 1994; Kestell, 2002). As considered in the Petkau Effect, the lower the concentration of reactive oxygen species present in body fluids, the greater the possibility for cells to be damaged and conversely, the more oxygen radicals created by radiation at higher doses, the faster they recombine and become ineffective before reaching and damaging the membrane (Petkau, 1971; Petkau, 1972; Graeub, 1994).

Red blood cells are optimal to detect the effects of low level doses of ionising radiation, as they may be the direct targets, or even scavengers of oxygen radicals species, while passing through organs and tissues in which generation of oxygen is increased. Also, as high concentrations of antioxidants and reducing agents in red blood cells make them effective scavengers of oxygen radicals, their passage through tissues undergoing oxidative stress may spare organ damage at the expense of red blood cells oxidation (Christopher, 1996).

In our study, the analysis of red blood cell parameters and hematological parameters indicated that the majority of cows bred in the area exposed to DU ammunition exhibited normocytic normochromic anemia.

RBC MDA is one of the end products of the peroxidation of membrane lipids, caused by free radical formations, especially by superoxide ion (Patockova et al., 2003). According to that, RBC MDA is a basic marker of oxidative stress. The concentration of RBC MDA was found to be more than 114 times higher in the exposed group of animals, indicating a violent oxidative stress. The significantly higher concentration of RBC MDA vs. control is consistent with data on oxidative stress studies (Christopher, 1996) and is also in agreement with other reports on the damages of erythrocytes plasma membrane induced by reactive oxygen species (Lunec, 1996). As previously described by Mattia et al. (1993a; 1993b) and Myhre et al. (2001), damage of erythrocytes plasma membranes induced by reactive oxygen species (ROS) may shorten the life span of these cells. Morphologically defined normocytic normochromic anemia indicates that there is no marked retikulocytosis, that corresponds to the fact that cows do not respond with increased retikulocyte count unless the anemia is profound. Therefore, disturbances of hematopoiesis, induced by different etiological factors, could not be excluded as a possible mechanism in the pathogenesis of detected anemia.

The other parameter in our study was the antioxidant enzyme SOD, that deactivates ROS and catalyzes transformation of toxic superoxid anion in $\mathrm{H}_{2} \mathrm{O}_{2}$, which cleaves to water and molecular oxygen (Cotgreave et al., 1988; Bogdan et 
al., 2000). Although RBC MDA concentrations were extremly high, the antioxidant enzyme SOD activity was unchanged, compared to the control group of animals. This indicates that the oxidative stress overwhelms SOD-antioxidative defense capacity, or could point at ROS induced damage in genes controlling production of superoxide dismutase, as previously described by Orr and Sohal (1994) and Powell and McMillan (1990).

Peripheral blood leukocytes circulate in a relatively passive, quiescent state. During inflammation or oxidative stress they are activated, expressing their functional activities, while their NADPH-oxidase system is capable to produce reactive oxygen species upon stimulation by cytokines or some bacterial products. In our study, all the exposed animals had the number of leukocytes and the differential leukocytes-count within the physiological range. The absence of leukocytes' respiratory burst, neither in spontaneous nor PMA stimulated NBT reaction, suggested that increased $\mathrm{RBC}$ MDA was not due to accompanying inflammation. Meanwhile, a decrease in spontaneous and PMA stimulated adhesiveness of peripheral blood granulocytes pointed at some kind of impairment functional activity of leukocytes.

The results of this study correlate with the data obtained in the study of oxidative stress in sheep bred in areas exposed to DU ammunition, which also confirmed that animals were exposed to strong oxidative stress and exhibited strong responsive anemia (Božic et al., 2003; Aleksić et al., 2004). The other study on damage of liver and kidney malfunction in animals from the same area confirmed the presence of plasma albumin polymers in both sheep and cows, and some protein modifications in sheep, indicating a harmful environmental impact, possibly due to radiation (Gađanski-Omerović et al., 2003).

The results of radioactivity measurements indicated that, although the region was exposed to DU ammunition (FM Report, 2000, UNEP Report 2001, 2002), it did not reache the soils and food/feed to a larger extent, mainly due to the fact that the contamination was local, around the targeted site, or the shells did not explode and therefore, possible contamination could be only due to the corrosion effect (UNEP Report, 2002).

\section{CONCLUSION}

The results on biochemical and hematological parameters suggests an existence of violent oxidative stress effects and anemia in cows bred in the area hit by DU ammunition. As the examined animals were clinically healthy, the results show that they were exposed to some serious disturbances in the environment. However, we cannot conclusively correlate the obtained data with the effects of DU that entered the environment and therefore, further studies are needed.

ACKNOWLEDGEMENTS:

The study was supported by the Ministry of Science, Technology and Development of the Republic of Serbia (Grant No.1518/2002). We wish to thank the veterinarians at the Veterinary Station Bujanovac, for great assistance in this work. 
Address for correspondence:

Prof. Jelka Stevanović

Department of Physiology and biochemistry

Faculty of Veterinary Medicine

Bul. Oslobođenja 18

11000 Belgrade

Serbia\& Montenegro

jelka@vet.bg.ac.yu

\section{REFERENCES}

1. Aleksić M, Lukić S, Jović S, Kovačević-Filipović M, Vlaški M, Božić T, Popović D, Stevanović J, 2004, Investigation of Oxidative Stress in Sheep Bred in Areas Exposed to Depleted Uranium (DU) Ammunition, Iugoslav Physio Pharmaco Acta, 40, 1-3, 139-44.

2. Berlin M, Rudell B, 1986, Uranium, in: Handbook on the toxicology of metals, $2^{\text {nd }}$ edition, L. Friberg GF, Nordberg and VB Vouk (eds), Elsever Science Publishers, Amsterdam, 623-37.

3. Bogdan C, Diefenbach A, Rollinghof M, 2000, Reactive oxygen and reactive nitrogen intermediates in innate and specific immunity, Current Opinion in Immunology, 12, 64-76.

4. Božić $T$, Kovačević-Filipović M, Borozan S, Popović D, Todorović D, 2003, Possible Effects Of Depleted Uranium (DU): I Changes In Cellular And Biochemical Values In Peripheral Blood Of Ruminants In Exposed Areas, Cent Eur J Occupat Environm Med, 9, 4, 267-72.

5. Christopher M, 1996, The red blood cells and antioxidative damage: innocent bystander or effective scavenger, Proceedings of the VII Congress of the International Society of Animal Clinical Biochemistry, Glasgow, 47- 9.

6. Cotgreave IA, Moldeus P, Orrenius S, 1988, Host biochemical defence mechanisms against prooxidants, Ann Rev Pharmacol Toxicol, 28, 188.

7. Cothern CR, Lappenbuch WL, 1983, Occurrence of uranium in drinking water in the US, Health Physiol, 45, 89-99.

8. Domingo JL, 2001, Reproductive and development toxicity of natural and depleted uranium: a review, Reproductive Toxicity, 15, 603-9.

9. Duraković A, 1999, Medical effects of internal contamination with uranium, Croat Med J, 40, 1, 4966.

10. FM REPORT, 2000, Consequences of NATO Bombing. Federal Ministry of Science and Environment, Belgrade.

11. Gađanski-Omerović G, Borozan S, Božić T, Popović D, 2003, Possible Effects Of Depleted Uranium (DU): II Damage of Liver and Kidney Mulfunction in Animals Of Exposed Areas, Cent Eur J Occupat Environm Med, 9, 4, 273-8.

12. Graeub R, 1994, Petkau Effect, The Devasting Effect of Nuclear Radiation on Human Health and the Environment, second ed., Four Walls Eight Windows.

13. Kestell D, 2002, SRP Scientific Meeting: Depleted Uranium Report, J Radiol. Protection, 22, 215-7.

14. Lee HA, Gabriel R, Bolton P, 2001, Depleted uranium - is it really a health issue? Lancet Oncology, 2, 197-206.

15. Lorimore SA, Wright EG, 2003, Radiation induced genomic instability and bystander effects: Related inflammatory type responses to radiation-induced stress and injury? Rev Int $J$ Radio Biology, 79, 1, 15-25.

16. Lunec J, 1996, Oxidative stress and antioxidants, Proceed. Of VII Congress of Inter. Soc. of Animal Clinical Biochemistry, 45-7.

17. Mattia CJ, Adams JD, Bondy SC, 1993a, Free radical induction in the brain and liver by products of toluene catabolism, Bioch Pharmacol, 46, 103-10.

18. Mattia CJ, Ali SF, Bondy SC, 1993b, Toluene induced oxidative stress in several brain regions and other organs, Mol Chem Neuropathol,18, 313-28.

19. Misra HP, Fridovich I, 1972, The role of superoxide anion in the auto oxidation of epinephrine and a simple assay for super oxide dismutase, J Biol Chem, 247, 3170-5. 
Acta Veterinaria (Beograd), Vol. 55. No. 4, 269-278, 2005.

Stevanović Jelka et al. A study on oxidative stress and peripheral blood parameters

of cows bred in the area exposed to depleted uranium ammunition

20. Monboisse JC, Garnotel R, Randoux A, Dufer J, Borel JP, 1991, Adhesion of human neutrophils to and activation by type-I collagen involving a $\beta 2$ integrin, $J$ Leukoc Biol, 50, 373-80.

21. Myhre O, Fonnum F, 2001, The effect of aliphatic naphtenic and aromatic hydrocarbons on production of reactive oxygen species and reactive nitrogen species in rat brain synaptosome fraction: the involvement of calcium, nitric oxide synthase, mitochondria, and phospholipase $A$, Biochem Pharmacol, 62, 118-9.

22. Nussbaum RH, Kohnlein W, 1994, Inconsistencies and open questions regarding low-dose health effects of ionising radiation, Environ Health Perspect, 102, 656-67.

23. Oez S, Welte K, Platzer E, Kalden JR, 1990, A simple assay for the quantifying the inducible adherence of neutrophils, Immunobiol, 180, 308-15.

24. Orr WC, Sohal RS, 1994, Extension of Life-Span by Over expression of Super oxide Dismutase and Catalyze in Drosophilae melanogaster, Science, 283, 1128-30.

25. Patockova J, Marhol P, Tumova E, Krisiak M, Rokyta R, Stipek S, Crkovska J, Andel M, 2003, Oxidative stress in the brain tissue of laboratory mice with acute post insulin hypoglycemia, Physiol Res, 52, 131-5.

26. Pellmar TC, Fuciarelli AF, Ejnik JW, Hamilton M, Hogan J, Strocko S, Emond C, Mottaz HM, Landauer $M R, 1999$, Distribution of uranium in rats inplanted with depleted uranium pellets, Toxicol Sci, 49, 29-39.

27. Petkau A, 1971, Radiation effect with a Model Lipid membrane, Can J Chemistry, 49, 1187-96.

28. Petkau A, 1972, Effect of $\mathrm{Na}^{22}$ on a Phospholipid Membrane, Healt Physics, 22, 239-44.

29. Popović D, Djurić G, Todorović D, 2002, Possible Impacts Of Depleted Uranium On Health And Environment: The Case Of Yugoslavia, Centr European J Occup and Environ Med, 8, 227-31.

30. Powell S, McMillan TJ, 1990, DNA damage and repair following treatment with ionising radiation, Radiother Oncol, 19, 95-208.

31. Ribera $D$, 1996, Uranium in the environment: occurrence, transfer, and biological effects, Rev Environ Contam Toxicol, 146, 53-89.

32. Roth P, Hoellriegl V, Werner E, Schramel P, 2003, Assessment of exposure to depleted uranium, Radiation Protection Dosimetry, 105, 1-4, 157-61.

33. Tentori L, Salvati AM, 1981, Haemoglobinometry in human blood, Meth Enzymol, 76, 707-15.

34. Todorović D, Radenković M, Popović D, Ivanov S, Djurić G, 2001, Contents of Radionuclides in the Region Of Stara Planina. Proceed. IV Regional Symposium Chemistry and Environment, Zrenjanin, 431-3.

35. UNEP Report, 2001, Depleted Uranium in Kosovo Post-Conflict Environmental Assessment. United Nation Development Program, Geneva.

36. UNEP Report, 2002, Post-Conflict Environmental Assessment Report On Depleted Uranium In Serbia and Montenegro, United Nations Development Program, Geneva.

37. Uchiyama $M$, Michara $M$, 1978, Determination of malondialdehyde precursors in tissue by thiobarbituric acid test, Anal Biochem, 86, 271-8.

38. Waterfall AH, Singh G, Fry JR, Marsden CA, 1997, The measurement of lipid poroxidation in vivo, Brain Res Brain Res Protoc, 2, 17-22. 


\title{
ISPITIVANJE OKSIDATIVNOG STRESA I PARAMETARA PERIFERNE KRVI KRAVA UZGAJANIH NA PODRUČJU IZLOŽENOM DEJSTVU MUNICIJE SA OSIROMAŠENIM URANIJUMOM (OU)
}

\author{
STEVANOVIĆ JELKA, KOVAČEVIĆ-FILIPOVIĆ MILICA, VLAŠKI MARIJA, \\ POPOVIĆ DRAGANA, BOROZAN SUNČICA, JOVIĆ S I BOŽIĆ TATJANA
}

\section{SADRŽAJ}

U radu su izneti rezultati istraživanja mogućih efekata osiromašenog uranijuma (OU) na zdravlje krava uzgajanih u području dejstava tokom NATO bombardovanja Srbije i Crne Gore, 1999 godine. Uzorci krvi, zemljišta i hraniva sakupljeni su u regionu Bujanovca 2003 godine. Životinjama je urađena kompletna krvna slika i ispitana je funkcionalna aktivnost njihovih leukocita. U eritrocitima istih krava je određena koncentracija pokazatelja oksidativnog stresa - maIondialdehida (RBC MDA) i aktivnost enzima antioksidativne odbrane - eritrocitne superoksid dismutaze (SOD). Standardnom metodom spektrometrije gama zračenja određena je aktivnost radionuklida u zemljištu i hrani.

Dobijeni rezultati ukazuju na postojanje normocitno normohromne anemije kod krava sa područja izloženih dejstvu OU. Značajno povećanje koncentracije RBC MDA, ukazuje da su životinje bile izložene jakom oksidativnom stresu, iako je aktivnost eritrocitnog antioksidnog enzima SOD bila u opsegu vrednosti dobijenih kod kontrolne grupe životinja. Ukupan broj leukocita i leukocitarna formula su bili fiziološkim granicama. Odsustvo leukocitnog oksidativnog praska, potvrđeno NBT redukcionim testom, isključuje postojanje inflamatornog procesa, dok značajno smanjenje adhezivnosti leukocita, ustanovljeno NBT adhezionim testom, upućuje na smanjenu funkcionalnu sposobnost leukocita krava koje potiču sa prostora izloženog uticaju OU. Aktivnost ${ }^{238} \mathrm{U} /{ }^{235} \mathrm{U}$ u zemljištu i hranivima je bila ispod minimalne koncentracije $\left(10^{-3} \mathrm{~Bq} / \mathrm{kg}\right) \mathrm{koja}$ se može izmeriti, dok je sadržaj prirodnih radionuklida ${ }^{226} \mathrm{Ra} i{ }^{232} \mathrm{Th}$, kao i antropogenog ${ }^{137} \mathrm{Cs}$ u zemljištu bio u opsegu srednjih vrednosti za region. Znatno niže vrednosti prirodnog ${ }^{40} \mathrm{~K}$ ukazuju na zemljište siromašno kalijumom.

Dobijeni rezultati nesumnjivo ukazuju da su ispitivane krave bile izložene snažnom oksidativnom stresu, ali zbog nedostatka pouzdanih podataka o distribuciji OU u životnoj sredini, ne možemo sa sigurnošću tvrditi da su ustanovljeni efekti posledica delovanja municije sa osiromašenim uranijumom. 